\title{
A combined combinatorial and pKa-based approach to ligand protonation states
}

\author{
Tim ten Brink, Thomas E Exner \\ From 5th German Conference on Cheminformatics: 23. ClC-Workshop \\ Goslar, Germany. 8-10 November 2009
}

The protonation of the ligand molecule and the protein binding site has a significant influence on the results obtained by protein-ligand docking. Due to the inability of X-ray crystallography to resolve the hydrogen atom in protein and protein complex structures, the correct protonation for the protein and the ligand has to be assigned on a theoretical basis before the structures can be used. Because of the local environment inside the binding site and because of the influence of the ligand and the protein onto each other, the ligand protonation can differ from the protonation one would expect for the ligand in solution under physiological conditions. Hence for protein-ligand docking different protonation states of the ligand have to be taken into account.

Our recently introduced structure preparation tool SPORES [1] used a rule based method to generate a standard protonation for each ligand molecule and afterwards generated different protonation states in a combinatorial way by adding and removing single hydrogen atoms belonging to predefined functional groups. Docking of all these protonation states of a given ligand molecule often led to scoring problems due to the different number of hydrogen interactions formed by the different protomers of the ligand molecule. To overcome these problems two methods to filter highly charged and unstable protonation states from the docking were implemented. One based on the difference between the standard protonation of the ligand and the actual protonation state and one based on $\mathrm{pKa}$ values calculated with ChemAxon's MARVIN software [2]. Here we present a new approach in which the ligand atoms considered for the combinatorial method not chosen from predefined functional groups but according

\footnotetext{
Department for Chemistry, University of Konstanz, D-78457 Konstanz,
} Germany to the calculated pKa values which leads to a wider variety but with a smaller overall number of protonation states.

Published: 4 May 2010

\section{References}

1. ten Brink T, Exner TE: J Chem Inf Model 2009, 49(6):1535-1546.

2. MARVIN 5.2.0, ChemAxon 2009 [http://www.chemaxon.com].

\section{doi:10.1186/1758-2946-2-S1-P43}

Cite this article as: ten Brink and Exner: A combined combinatorial and pKa-based approach to ligand protonation states. Journal of Cheminformatics 2010 2(Suppl 1):P43.

\footnotetext{
Publish with ChemistryCentral and every scientist can read your work free of charge

"Open access provides opportunities to our colleagues in other parts of the globe, by allowing anyone to view the content free of charge." W. Jeffery Hurst, The Hershey Company.

- available free of charge to the entire scientific community

- peer reviewed and published immediately upon acceptance

- cited in PubMed and archived on PubMed Central

- yours - you keep the copyright

Submit your manuscript here:

http://www.chemistrycentral.com/manuscript/

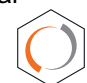
ChemistryCentral
} 